\title{
Effects of Cinnamaldehyde on Salivary Gland Tissue in Xerostomia Model
}

\author{
Ja-Hyeong Choi ${ }^{1, *}$, Jung-Hwa Lee ${ }^{2, *}$, Yeon-Hwa Kim ${ }^{3, *}$, Kyung-Yae Hyun ${ }^{4, *}$, \\ Chung-Mu Park ${ }^{4, *}$ and Min-Kyung Lee $\mathrm{e}^{2, \dagger, *}$ \\ ${ }^{I}$ Department of Dental Hygiene, Kyung-Woon University, Gumi 39160, Korea \\ ${ }^{2}$ Department of Dental Hygiene, Dong-Eui University, Busan 47340, Korea \\ ${ }^{3}$ Department of Dental Hygiene, Ulsan College, Ulsan 44022, Korea \\ ${ }^{4}$ Department of Clinical Laboratory Science, Dong-Eui University, Busan 47340, Korea
}

\begin{abstract}
Xerostomia is a relatively common oral disease that causes various problems such as pain, discomforted, tissue damage, and infection. When the activity of AQPs, which plays an important role in the microbial channel transmembrane activity in tissues, decreases saliva secretion and the oral cavity dryness occurs. In this study, we observed whether there was a change in tissue through the expression level of AQP-5 in the submandibular gland in the 4-DAMP-induced xerostomia model. First, in order to construct a xerostomia model, 4-DAMP $(1 \mathrm{mg} / \mathrm{kg})$ and $20 \%$ urethane $(0.5 \mathrm{~mL} / \mathrm{kg})$ were administered intraperitoneal (i.p.) to experimental animals. To observe the changes in the submandibular gland was excised, $H \& E$ staining was performed and protein quantitation analysis was performed using the submandibular tissue to observe the changes in AQP5 protein expression involved in changes in saliva secretion. Also, cinnamaldehyde (5, $12.5,25$ and $50 \mathrm{mg} / \mathrm{kg}$ ) dissolved in $20 \%$ DMSO, in distilled water for each concentration, and then orally administered at a dose of $1 \mathrm{~mL}$ for biopsy and protein quantitative analysis. As a result, it was observed that the submandibular tissue, a model of xerostomia was wider than the naïve group. And then western blot analysis, the expression level of AQP5 decreased in the 4-DAMP group compared to the naïve group, and the expression increased in the group administered orally with cinnamaldehyde. Therefore, administration of 4-DAMP resulted in histological changes for xerostomia, and cinnamaldehyde would be a material that can be developed by reducing xerostomia.
\end{abstract}

Key Words: Xerostomia, AQP5, 4-DAMP, Submandibular gland

\section{서 론}

구강건조증은 주관적으로 입이 마르는 증상을 말하는 것으로 통증, 저작의 불편함, 조직 손상 및 감염과 같은 다양한 문제를 야기하는 비교적 일반적인 구강 질환이 다(Hopcraft and Tan, 2010). 통상적으로 비 자극 시에는 $0.1 \mathrm{~mL} / \mathrm{min}$ 이하, 자극 시에는 $0.5 \sim 0.7 \mathrm{~mL} / \mathrm{min}$ 이하의 타
액이 분비되는 경우에 타액분비저하증(hyposalivation)으로 정의하는데, 타액 분비의 기능적인 문제가 아닌 구호흡 과정에서도 입 안의 수분이 증발되면서 주관적인 건조 증 상을 호소하기도 한다(Choi and Lim, 2016).

타액은 신경세포 말단에서 방출된 아세틸콜린과 노르 에피네프린에 의해 촉진되어 부교감 신경의 자극과 교 감 신경의 자극으로 분비가 진행된다(Ishikawa and Ishida, 2000). 부교감 신경의 자극은 타액선 내의 무스카린 수

Received: June 4, 2020 / Revised: June 22, 2020 / Accepted: June 23, 2020

* Professor.

${ }^{\dagger}$ Corresponding author: Min-Kyung Lee. Department of Dental Hygiene, Dong-eui University, 176 Eongwangno(gayadong san24), Busanjin-gu, Busan 47340, Korea.

Tel: +82-51-890-4238, Fax:+82-0505-182-6878, e-mail: lmk849@deu.ac.kr

(C) The Korean Society for Biomedical Laboratory Sciences. All rights reserved.

(@) This is an Open Access article distributed under the terms of the Creative Commons Attribution Non-Commercial License (http://creativecommons.org/licenses/by-nc/3.0/) which permits unrestricted non-commercial use, distribution, and reproduction in any medium, provided the original work is properly cited. 
용체를 자극하여 장액성 타액 분비를 유도하고, 교감 신 경의 자극은 타액선의 아드레날린 수용체 자극에 의한 점액성 타액 분비를 유도한다(Screebny and Valdini, 1987). 타액선에는 타액의 분비를 일으키는 무스카린 수용체 (Muscarinic receptor, M)가 분포하고 있으며, M1-M5으로 5 개의 뚜렷한 무스카린성 수용체의 아형이 존재하는 것으 로 알려져 있으며, 이들 수용체는 신체 내에서 서로 다르 지만 유기적인 상호작용을 하고 있다(Neda et al., 2017). 무 스카린 수용체의 활성 및 기전은 아세틸콜린(Acetylcholine, $\mathrm{ACh}$ )과 관련되는데, $\mathrm{ACh}$ 은 Choline과 acetyl coenzyme A 에 choline acetyl transferase가 작용하여 생성된 것으로 세 포 외 배출로 인하여 acetyl cholinesterase에 의해 대사되 어 choline을 방출한다(Caulfueld and Birdsall, 1998). ACh은 심장의 기능을 수행하는 $\mathrm{M} 2$ 수용체 및 안구의 기능을 조 절하는 M4 수용체는 억제하는 반면, 중추 신경과 말초 신경절에 작용하는 $\mathrm{M} 1$ 수용체는 흥분 성으로 $\mathrm{ACh}$ 의 방 출을 촉진시키며, 선택적 막인 무스카린 M3 수용체는 타 액선 기능에 관여하는 것으로 $\mathrm{ACh}$ 이 결합하여 수축성 단백질이 활성화가 나타나게 되면서 타액이 방출된다 (Caulfueld and Birdsall, 1998).

타액이 세포를 통과하는 경로는 두 가지로 세포 간 결 합 부위를 통과하거나 세포를 가로질러 말단부와 기저부 세포막을 통과하는 경로로 이루어지는데, 물과 관련된 원 형질막에서의 내재적 투과성 능력은 낮은 편이므로 세포 를 가로질러 물을 이동시키기 위하여 기저 부와 말단부 세포막에는 각각의 물의 통로가 있다(Agre et al., 2002). 타액 분비에 중요한 역할을 하는 아쿠아포린(Aquaporins, $\mathrm{AQPs})$ 은 세포막 단백으로 4 개의 하부 단위로 구성되어 있고, 각각은 6 개의 물을 투과할 수 있는 구멍을 형성하 는 세포막 간 영역이 있다(Smith et al., 1999). 현재까지는 $\mathrm{AQP} 0 \sim \mathrm{AQP} 12$ 의 13 개의 채널이 있는 것으로 밝혀져 있으 며 유체의 신속하고 규제된 운송이 필요한 조직 뿐만 아 니라, $\mathrm{AQPs}$ 가 수질 대사에 중요한 역할을 필요로 하는 다 른 조직에서도 많이 발견된다(Matsuzaki et al., 1999). AQPs 중에서 $\mathrm{AQP} 1, \mathrm{AQP} 3, \mathrm{AQP} 4, \mathrm{AQP} 5$ 및 $\mathrm{AQP} 8$ 이 타액선에 서 확인되었으며, 특히 $\mathrm{AQP} 3, \mathrm{AQP5}$ 및 $\mathrm{AQP} 8$ 은 사람과 쥐의 세포에서 발견할 수 있다(Matsuzaki et al., 1999). 그 중 AQP5는 수분 채널 단백질로써 원형질막을 가로지르 는 수분의 이동에 중요한 역할을 하며 이하선, 설하선 및 악하선 세포에서 발견되었으며 세포 간 분비물을 포함한 기저 부와 말단부 막에서 관찰된다(Toshiyuki et al., 1999). 이소프로테레놀(isoproterenol)에 의한 자극 시, 편평상피
세포에서 $\mathrm{AQP5}$ 에 대한 첨단 부 염색을 통하여 세포막 근 처로 편중되어 있는 점 상의 형태를 관찰할 수 있었고 이 러한 결과는 $\mathrm{AQP5}$ 가 타액선에서 수분 이동을 담당하는 후보 분자 중 하나임을 시사한다(Toshiyuki et al., 1999). 단 백정량분석을 통해서 정상/비만 당뇨병 마우스를 이용한 구강건조증 동물실험 모델의 악하선에서 구강건조증군 의 AQP5 발현이 정상 군보다 낮았다는 보고(Satoh et al., 2013)가 있었고, 대동맥 림프절의 부교감 신경을 차단했을 경우 고삭신경절에 의하여 악하선의 AQP5 발현을 $37 \%$ 대로 감소시켰다는 연구결과(Li et al., 2008)도 있다. 따라 서 부교감 신경계에 AQP5 뿐만 아니라 악하선이 많이 의존한다는 것을 의미한다. 본 연구에서도 복강 내 4$\mathrm{DAMP}$ 를 투여하여 타액선 손상을 동반하는 구강건조증 을 유발시킨 뒤, 타액선 손상 전후의 세포막 첨단에 위치 한 AQP5의 발현의 변화와 타액선 조직 변화를 확인해 보고자 하였다.

현재까지, 구강건조증의 대표적인 치료제로 사용되는 필로카르핀(pilocarpine)과 세비멜린(cevimeline)은 미국 식 품의약국(FDA)의 승인을 받은 타액 분비 촉진제다. 필로 카르핀은 무스카린 수용체의 부교감 신경을 자극하고, 세 비멜린은 M3 무스카린 수용체와 강한 친화성 결합력을 나타내는 타액선 자극제로 사용되고 있다(Choi and Lim, 2016). 효능이 좋은 반면 부작용도 적지 않은데 현재 보 고된 부작용을 살펴보면 땀 분비의 증가, 피부 혈관의 확 장, 오심 및 구토, 설사, 딸꾹질, 기관지 축소, 저혈압, 빈 맥, 증가된 빈뇨, 시야의 이상 등을 초래할 수 있으며, 특 히 필로카르핀은 협각 녹내장이나 홍채 염 환자에게 금 기가 될 수 있다(Aframian et al., 2007). 최근에는 이러한 합성 의약품 부작용을 감소시키기 위하여 구강건조증을 비롯한 다양한 질환 처치를 위한 천연 물질의 약리적 효 능에 대한 관심이 높아지고 있다. 약리적 효능을 가지고 있으면서 비교적 독성이 낮고 장기적으로 복용하여도 초 래되는 부작용이 비교적 적어서 천연 물질에 대한 연구가 활발하게 진행되고 있다(Braga et al., 2009). 본 연구에서 사용된 cinnamaldehyde는 녹나무 속에 속하는 cinnamon oil 의 주성분으로써 질병의 발생 억제와 조절을 위하여 과 거부터 사용되고 있는 식품 및 약품이다. Cinnamon은 항 산화 작용을 향상시키는 폴리페놀 성분이 풍부한 것으로 알려져 있으며 항염제, 설사 방지제, 항응고제 및 각성제 효과가 있고(Hossein et al., 2013), 강력한 항산화 및 항염증 특성으로 인하여 신경, 간, 심장 보호 및 위장 보호 효과 등의 연구가 밝혀지고 있지만 구강건조증과 관련된 연구 
는 거의 전무한 실정이다.

따라서 본 연구에서는 실험동물을 대상으로 4-DAMP를 복강 내로 투여하여 타액선 손상을 동반한 구강건조증 모 델을 구축하고, cinnamaldehyde를 경구로 투여하여 악하선 의 조직 변화 및 $\mathrm{AQP5}$ 의 발현 량의 변화에 미치는 효과 를 확인하고자 하였다.

\section{재료 및 방법}

\section{실험동물}

본 연구에서 사용된 Sprague-Dawley계 생후 6 7주령의 실험동물은 효창사이언스(대구)에서 공급받았으며 200 $230 \mathrm{~g}$ 의 수컷 흰 쥐를 사용하였다. 동의대학교 동물준비 실에서 사육하였으며 12 시간 주.야간 빛의 순환 주기와 $23 \sim 26^{\circ} \mathrm{C}$ 온도로 일정하게 유지하였다. 본 연구는 의식 있는 동물에 대한 통증연구학회에서 규정한 윤리 규범을 준수하여 진행하였고, 동의대학교 동물실험윤리위원회에 서 승인을 받았다(R2018-011).

\section{약물 제조 및 약물 투여 방법}

4-DAMP 투여 및 타액 분비량 측정: 스트레스를 최소화 하기 위하여 실험 시작하기 30분 전부터 투명한 플라스틱 통에 적응시켰고, 실험을 진행하기 전까지 물과 사료의 일체 섭취를 금지하였다. 4-DAMP는 구강건조증을 유발 하기 위하여 사용되는 약물로 시그마 알드리치사(SigmaAldrich Co., St. Luis, U.S.A)에서 구입하였다. 4-DAMP (1 mg/ $\mathrm{kg}$ )를 복강 내에 $1 \mathrm{~mL}$ 의 용량으로 투여(intraperitoneal)하여 타액선 손상을 유도하였고, 1 시간 경과 후 $20 \%$ urethane $(0.5 \mathrm{~mL} / \mathrm{kg})$ 을 복강 투여하여 안정 위 상태를 유지하였다. 악하선의 분비관 개구 부위에 멸균된 면 구(cotton ball)를 위치시킨 뒤 30 분 간 타액을 흡수하여 무게를 측정하여 타액 분비량으로 간주하였다. 대 타액선 중 이하선은 저 작 시 분비되는 자극성 타액을 주로 분비하고 설하선은 자극성, 비자극성 타액 분비 모두에 관련되며, 악하선은 안정 시 고여 있는 비자극성 타액을 주로 분비한다. 따라 서, 본 실험에서는 마취 하에서는 안정 위 상태이므로 비 자극성 분비 조직인 악하선을 실험대상으로 진행하였다.

구강건조증과 관련된 생체반응 측정: 4-DAMP 투여 후 일 주일 간 음수 량, 식이 섭취량 및 체중 변화를 구강건조 증과 관련된 생체 반응으로 간주하여 측정하였고, 유의한 변화를 나타낸 실험동물을 기준으로 구강건조증 모델을
확립하였다. 음수 량은 물병에 $250 \mathrm{~mL}$ 의 물을 담고 매일 잔여 량을 확인하여 일주일 경과 후 실제 복용량을 측정 하였으며, 식이 섭취량은 실험동물에게 $200 \mathrm{~g}$ 의 사료를 제공하고 일주일 후 잔여 량을 정량하여 식이 섭취량을 측정하였다. 체중은 실험 전 후 체중계로 측정한 뒤 기록 하여 변화를 관찰하였다.

Cinnamaldehyde의 약물 조제: Cinnamaldehyde는 시그 마 알드리치사(Sigma-Aldrich Co., St. Luis, U.S.A)에서 구입 하여 사용하였으며, 4-DAMP를 복강 투여하기 30분 전에 cinnamaldehyde를 경구로 투여하여 타액선 조직 변화에 미치는 영향을 평가하였다. $20 \% \mathrm{DMSO}$ 에 용해한 cinnamaldehyde는 distilled water (D.W)에 $5,12.5,25,50 \mathrm{mg} / \mathrm{kg}$ $(1 \mathrm{~mL})$ 의 농도로 희석하여 각각 경구 투여하였다.

\section{조직 적출과 헤마톡실린-에오신(H\&E) 염색}

4-DAMP (1 mg/kg)를 복강 투여하여 타액선 손상을 유 발하고 24 시간 경과 후 $20 \%$ urethane $(0.5 \mathrm{~mL} / \mathrm{kg})$ 을 복강 투여하여 마취하였다. 실험동물이 마취가 된 것을 확인한 다음 조직 적출 예정인 안면 부위에 털과 수염을 미리 제 모하였고, 이어 우측 악하선 조직을 적출하였다. 4-DAMP 투여 30 분 전 농도 별 cinnamaldehyde를 투여한 실험 군 도 동일한 방법으로 조직 적출하였다. 적출된 악하선 조 직의 손상 정도와 cinnamaldehyde의 농도 별 경구 투여로 인하여 변화된 조직 세포의 형태 등을 관찰하기 위하여 $\mathrm{H} \& \mathrm{E}$ 염색을 실시하였다. 적출된 조직은 24시간 동안 $10 \%$ neutral buffered formalin 용액에 담가 고정시킨 뒤 $60^{\circ} \mathrm{C}$ 건조기에서 파라핀을 녹였다. 다음은 탈 파라핀 과 정으로 자일렌으로 5 분간 3 회 실시하였으며 $50,60,70$, $80,90,95 \%$ 무수에탄올 I에서 무수에탄올 II로 탈수 과정 을 거쳤다. 마지막으로 명확한 조직검사를 위하여 고형화 된 block을 얇게 절단한 뒤 광학 한미경(CX22LEDRFS; Olympus co., Tokyo, Japan)으로 관찰하였으며, 디지털 카메 라로 사진 촬영하였다.

\section{단백정량분석}

단백정량분석은 4-DAMP 또는 농도 별 cinnamaldehyde 를 복강 투여하고 24시간 경과 후 악하선 조직을 적출한 뒤 AQP5의 양적 변화를 확인하고자 하였다.

적출한 악하선은 RIPA lysis buffer (biosesang, Gyeonggi-do, Korea)를 첨가하여 $4{ }^{\circ} \mathrm{C}$ 에서 homogenizer (T 10 basic ULTRA -TURRAX ${ }^{\circledR}$, IKA, Staufen, Germany)를 이용하여 균질화 하 
였다. 그 후 $4{ }^{\circ} \mathrm{C}$ 에 $14,000 \mathrm{rpm}$ 으로 Centrifuge (1730MR, gyrozen, Seoul, Korea)에서 10 분 간 원심분리 한 뒤 상층 액을 분리하여 단백질의 흡광도를 측정하였다. 그 다음 LDS sample buffer (4X, Bolt ${ }^{\mathrm{TM}}$, thermofisher scientific, Seoul, Korea)와 reducing agent (10X, thermofisher scientific, Seoul, Korea), D.W를 혼합하여 $70^{\circ} \mathrm{C}$ 에서 10 분 간 heating 시킨 뒤 vortexing 하였다. 정량 된 단백질 sample은 polyacrylamide gel (Bolt ${ }^{\circledR} 4 \sim 12 \%$ Bis-Tris Plus gels, 15 well. thermofisher scientific, Seoul, Korea)에 $18.5 \mu \mathrm{L}$ 로 loading 한 다음 $200 \mathrm{~V}$ 에서 22 분간 running 과정을 거쳤다. $20 \mathrm{~V}$ 로 1 시간 동안 transfer하여 gel에서 PVDF membrane $(0.45 \mu \mathrm{m})$ 으로 단백질 을 옮겼다. Blocking buffer (1X PBST, 5\% skim milk, sodium

azide)에 2시간 blocking 한 뒤 1X PBST (10X PBST, D.W, $0.1 \%$ Tween 20)로 5회 수세 후 1차 antibody (Ab)로는 GA(P)DH mouse monoclonal Ab (1:2,000, santa cruz biotechnology, INC., Texas, USA)와 AQP5 rabbit polyclonal Ab (1: 5,000 , abcam, Cambridge, UK )를 $4^{\circ} \mathrm{C}$ 에서 overnight 시켰 다. $1 \mathrm{X}$ PBST로 재 수세 후 교반기 위에서 2차 $\mathrm{Ab}$ 를 2시 간 실온에서 부착하였고 $\mathrm{GA}(\mathrm{P}) \mathrm{DH}$ 와 $\mathrm{AQP} 5$ 의 2차 $\mathrm{Ab}$ 는 각각 rabbit anti-mouse IgG (Abcam, MA, USA)와 goat antirabbit IgG (Abcam, MA, USA)를 1:10,000의 비율로 사용 하였다. 발현은 ECL select (Amersham Pharmacia Biotech, Buckinghamshire, UK)을 이용하여 분석하였다.
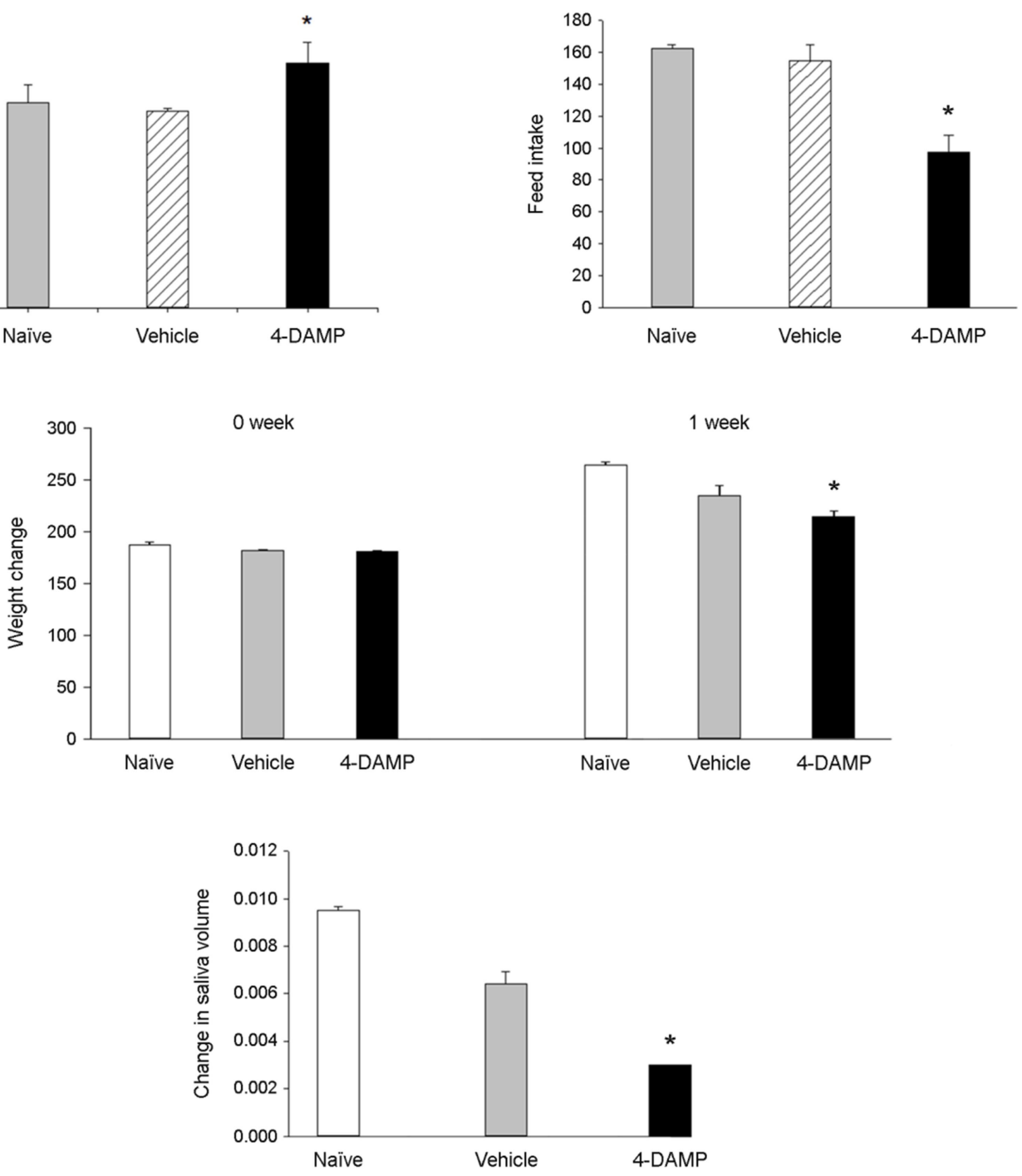

Fig. 1. Bioresponse changes after induction following by 4-DAMP of xerostomia $\left({ }^{*} P<0.05\right.$, vs vehicle, $\left.\mathrm{n}=6\right)$. 

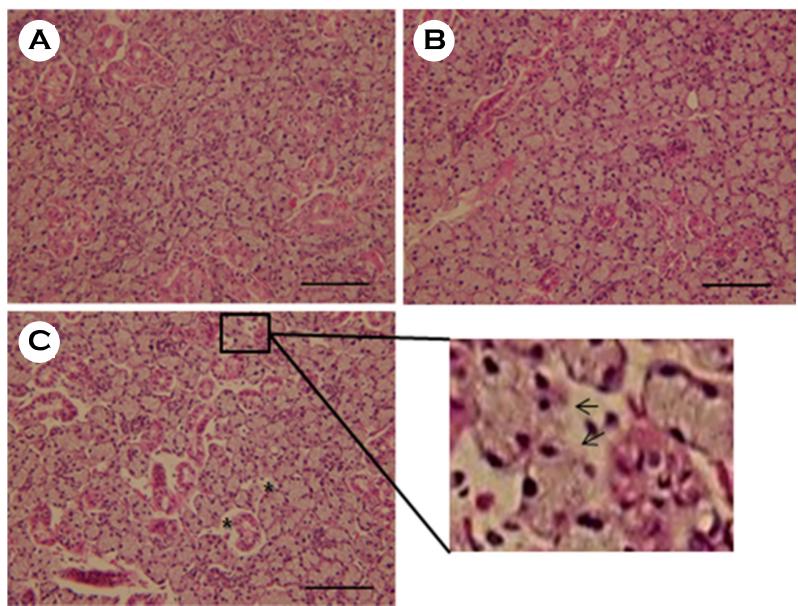

Fig. 2. Observation of the mandibular gland through $\mathrm{H}$ \& $\mathrm{E}$ staining after 4-DAMP administration (400 $\times$, image). Naive $(A)$, vehicle (B), 4-DAMP administration (i.p) (C). (scale bar $=200 \mu \mathrm{m})(\mathrm{n}=3)$.

\section{통계분석}

구강건조증 관련 생체반응 결과와 악하선 조직 실험결 과의 통계 분석은 IBM SPSS statistic ver. 22 (IBM Co., Armonk, NY, USA)을 사용하였다. 반복 측정 자료의 일원 분산분석을 시행하였고 사후 분석은 LSD post-hoc test를 이용하였으며, 모든 결과는 통계적 유의 수준을 $P<0.05$ 기준으로 하였으며, 평균 \pm 표준 편차를 오차(SEM)로 표 기하였다.

\section{결 과}

\section{4-DAMP 투여에 의한 구강건조증 모델 확립}

Fig. 1은 4-DAMP를 복강 투여하여 타액선 손상을 동 반한 구강건조증을 유발시킨 다음 구강건조증과 관련된 생체반응 변화이다. 실험 전 음수 량, 식이 섭취량, 체중 및 타액유출량을 안정 위 상태에서 우선 측정하였고, 4DAMP 투여 일주일 후 다시 측정하여 비교한 결과를 나 타내었다. 음수 량은 아무런 처치를 하지 않은 naïve 군에 서 $190 \mathrm{~mL}$, 증류수를 투여한 vehicle 군 $167.5 \mathrm{~mL}, 4$-DAMP 투여 군에서 $208.8 \mathrm{~mL}$ 으로 확인되었고, 식이 섭취량의 변 화의 측정값은 naïve 군 $162.5 \mathrm{~g}$, vehicle 군 $155 \mathrm{~g}$, 4-DAMP 군 $97.5 \mathrm{~g}$ 으로 4-DAMP 투여한 실험 군에서 섭취량이 감 소하였다. 체중 변화는 naïve 군 $265 \mathrm{~g}$, vehicle 군 $235 \mathrm{~g}$ 에 비하여 4-DAMP 군에서 $215 \mathrm{~g}$ 로 체중이 통계적으로 유의 하게 감소한 것을 확인할 수 있었으며 마지막 타액 분비
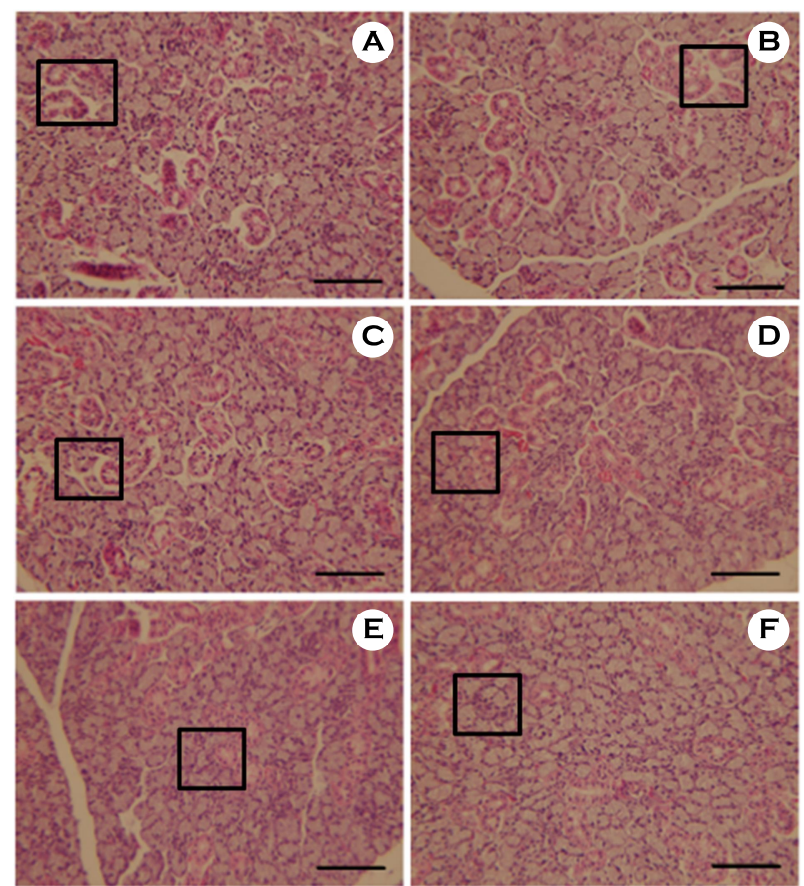

Fig. 3. Effect of cinnamaldehyde on tissue changes in the submandibular gland (Hematoxylin and Eosin staining, 400×, image) (A-E). 4-DAMP (A), vehicle (B), Cinnamaldehyde (5 mg/kg) (C), Cinnamaldehyde $(12.5 \mathrm{mg} / \mathrm{kg})$ (D), Cinnamaldehyde $(25 \mathrm{mg} / \mathrm{kg})$ (E), Cinnamaldehyde $(50 \mathrm{mg} / \mathrm{kg})(\mathrm{F})$ (scale bar $=200 \mu \mathrm{m}, \mathrm{n}=3)$.

량은 naïve 군 $0.0095 \mathrm{~mL}$, vehicle 군 $0.0064 \mathrm{~mL}, 4-\mathrm{DAMP}$ 군 $0.0030 \mathrm{~mL}$ 로 4-DAMP 투여 군에서 naïve 군과 vehicle 군에 비하여 통계적으로 유의하게 감소하였다. 정리하면 구강건조증을 유발시킨 실험동물에서 음수 량이 증가한 반면, 식이 섭취량, 체중, 타액 량은 모두 감소한 것을 확 인할 수 있었으며 모두 통계적으로 유의하였다 $(P<0.05)$.

또한 Fig. 2는 4-DAMP 투여에 의한 조직의 변화이다. Naïve 군과 vehicle 군 및 4-DAMP 약물 투여 후 적출된 악하선 조직의 변화를 살펴보면 naïve 군과 vehicle 군 간 에는 큰 변화 양상은 관찰되지 않는 것에 비하여 4-DAMP 투여 후 적출된 조직에서는 세포 사이 간극이 넓고 세포 막의 경계가 희미한 것을 관찰할 수 있었다.

\section{Cinnamaldehyde 투여에 따른 악하선 조직의 변화}

농도 별 cinnamaldehyde를 경구 투여한 구강건조증 모 델에서 확인된 악하선 조직의 변화를 Fig. 3에 나타내었 다. Naïve 군과 vehicle 군 사이에서는 별다른 차이를 보이 지 않은 반면, 4-DAMP 군에서는 세포 부피가 수축하여 세포 사이 간극이 벌어져 있으며 세포막의 경계 부위가 

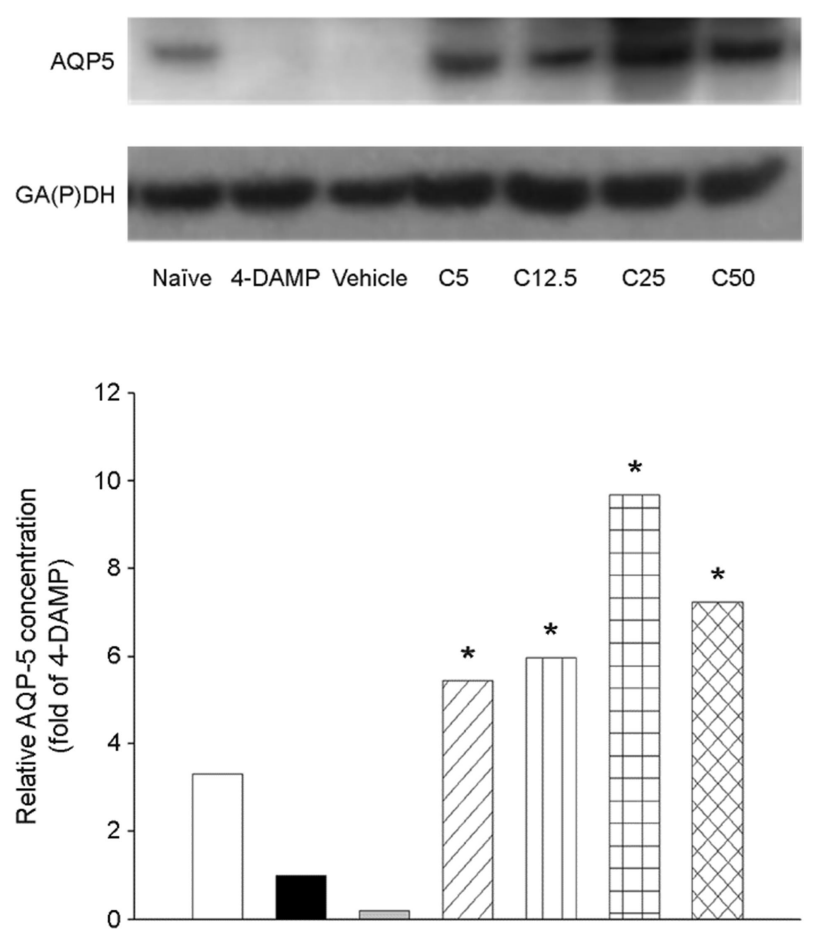

Fig. 4. Western blotting analysis of AQP5 after administration of cinnamaldehyde, an antibody of the protein soluble substance of submandibular gland in rat (vehicle: 4-DAMP + D.W) $\left({ }^{*} P<0.05\right.$, vs 4-DAMP, $n=3$ ).

흐릿한 것을 관찰할 수 있었다. 그에 반해 cinnamaldehyde 투여 군에서는 농도 의존적으로 조직의 회복이 효과적으 로 나타난 것으로 확인되었다. 특히 조직 cinnamaldehyde $25 \mathrm{mg}$ 과 $50 \mathrm{mg}$ 군에서 세포 간극이 좁아지고 세포막 경 계 부위도 선명해져 회복력이 높은 것으로 확인할 수 있 었다.

\section{Cinnamaldehyde 투여에 따른 AQP5 발현의 변화}

4-DAMP 투여로 유발된 악하선 손상에 따른 AQP5의 발현의 변화를 단백정량분석을 통해 확인하였고, cinnamaldehyde를 농도 별로 경구 투여한 다음 나타나는 악하선 조직 내 AQP5 발현 량 차이를 확인해보았다. 아무런 처 치를 하지 않은 Naïve 군과 비교해 보았을 때, 구강건조 증상이 발현되는 4-DAMP 군 및 4-DAMP 투여 후 증류수 를 투여한 vehicle 군에서는 $\mathrm{AQP} 5$ 에서 단백질 발현 량이 현저히 감소된 것으로 관찰되었고, cinnamaldehyde 투여 한 군에서 AQP5의 발현 량이 증가되었다(Fig. 4). 이러한 결과를 그래프 화하여 살펴보면, 4-DAMP를 수치 1 을 기 준으로 naïve 군 3.31 과 vehicle 군 0.19 에 비하여 cinnam- aldehyde $5 \mathrm{mg} 5.44$, cinnamaldehyde $12.5 \mathrm{mg} 5.59$, cinnamaldehyde $25 \mathrm{mg} 9.68$, cinnamaldehyde $50 \mathrm{mg} 7.24$ 였으며 통 계적으로 유의하였다. 이러한 결과를 통하여 cinnamaldehyde의 투여에 의한 조직 변화는 AQP5의 발현에 의 해 조절된 결과라고 유추할 수 있었다.

\section{고 찰}

본 연구는 무스카린 $\mathrm{M} 3$ 수용체의 선택적인 차단제인 4-DAMP를 복강으로 주입하여 타액선 손상을 동반하는 구강건조증을 확립하고, cinnamaldehyde의 투여에 의한 손 상된 악하선의 조직 변화 및 AQP5 신호 체계의 역할을 확인하고자 하였다. 우선 4-DAMP의 투여 후 악하선 조 직 변화와 생체 반응의 변화를 바탕으로 하여 타액선의 손상 여부를 확인하였다.

4-DAMP를 복강 투여 후 면 구를 악하선 개구 부에 위 치시킨 뒤 30 분 동안 무게를 측정한 결과 타액 분비량이 통계적으로 유의하게 감소하였으며 음수 량은 증가한 반 면 식이 섭취량과 체중 증가 량이 naïv 군에 비해 감소 된 것을 확인할 수 있었다. 타액 분비량이 감소함에 따라 저작의 용이성과 소화 작용에 도움되는 윤활 작용이 감소 하여 식이 섭취가 원활하게 이루어지지 않아 실제 식이 섭취량이 naïve 군에 비하여 낮은 수치를 보였고, 결과적 으로 체중 증가 폭도 낮게 나타났다. 이러한 실험결과는 실제 임상적인 구강건조증의 증상들과 유사한 결과로 볼 수 있고, 본 실험 모델의 임상적 의의를 제시할 수 있다.

악하선을 적출한 뒤 $\mathrm{H} \& \mathrm{E}$ 염색을 통하여 보여지는 세 포 변화의 결과는 세포 사이 간극이 넓어졌고 세포 첨단 막의 경계가 희미해지는 세포 조직의 이상을 관찰할 수 있었고, 단백정량분석을 통한 악하선 조직 변화를 확인한 결과, 4-DAMP 투여로 의한 구강건조증의 유발로 AQP5 의 발현 량이 극명하게 감소한 것을 관찰할 수 있었다. 최근 연구결과에 따르면 구강건조증 증상을 보이는 쇼그 렌증후군 환자의 악하선을 적출하여 정상 세포와 비교를 한 조직에서 실험 군의 악하선에서 세포 사이 간극이 넓 고 세포 형태가 변형된 것이 보고되었고(Quartuccio et al., 2017), 이것은 타액선 세포 손상 및 세포 기능 저하는 구 강건조증 증상의 하나인 타액유출량이 감소를 초래할 수 있다는 것을 의미한다.

뿐만 아니라, 4-DAMP를 정맥 내 투여하여 구강건조증 을 유발시킨 흰 쥐 모델에서 byakkokaninjinto을 투여하였 을 때 $\mathrm{M} 3$ 수용체의 활성화 및 타액 분비가 용량 의존적 
으로 증가되었고, 단백정량분석을 통해 AQP5의 발현이 증가된다는 연구결과가 보고되었다(Yuichiro et al., 2008). $\mathrm{AQPs}$ 는 세포의 혈관과 내강 사이를 연결하는 파이프 역 할을 하며 수분의 운반 과정에 관여하게 되는데, 그 중 $\mathrm{AQP} 5$ 는 선포 세포의 기저막 층과 세포 사이 분비소관을 포함한 세포 측 막에 존재하며 아세틸콜린과 에피네프 린에 의하여 M3 무스카린 수용체에 작용하여 세포질 내 $\mathrm{Ca}^{2+}$ 농도를 높임으로써 내강 측면 세포막의 AQP5를 증가시켜 타액이 통과하는 통로가 열리게 되는 것이다 (Melvin et al., 1988). 세포막 자체에는 물 투과성이 낮아 $\mathrm{AQPs}$ 라는 특수한 형태의 단백질을 통해서 물이 이동한 다는 사실이 밝혀지면서 $\mathrm{AQPs}$ 와 타액 분비에서의 물 이 동의 연관성을 확인하는 연구결과들이 있었다(Kim, 2004). Pilocarpine을 이용한 마우스 실험에서 타액 생성이 AQP5 유전성 돌연변이(AQP5 knockout mice) 군에서 naïve 군에 비해 $60 \%$ 이상 감소한 결과를 확인할 수 있었고(Ma et al., 1999), Murdiastuti 외의 연구(Murdiastuti et al., 2006)에서도 AQP5 knock out mice 군에서 악하선 세포의 단백정량분석 실험에서 AQP5의 발현이 매우 낮고 타액선에서 타액의 분비가 감소한다는 연구결과가 보고되었다. 이러한 선행 연구를 비롯한 본 실험의 결과를 통하여 AQP5의 발현이 억제되면 타액 분비가 감소된다는 것을 관찰할 수 있고, 타액 분비 후 수분의 이동 과정에서 AQP5는 중요한 역 할을 담당한다는 것을 확인할 수 있다.

Cinnamaldehyde는 항산화 및 항염증 작용을 가지고 있 는 천연물로써 4-DAMP 투여하여 유도된 구강건조증 모 델에서 cinnamaldehyde의 군에서 세포 사이 간극이 협소 해지며 세포막 경계 부위가 뚜렷해지는 결과를 보였으며, cinnamaldehyde의 농도에 따라 의존적으로 손상된 조직 회복성이 높은 것을 확인할 수 있었다. 또한 단백정량분 석 실험에서도 cinnamaldehyde 투여 군이 4-DAMP 군에 비하여 AQP5의 발현 량이 증가하였고 이는 통계적으로 유의한 것을 확인하였다. Yuichiro 외의 연구(Yuichiro et al., 2008)에서 사포닌을 함유하고 있는 인삼 뿌리과 천연물인 byakkokaninjinto을 투여하였을 때 4-DAMP로 유도 하여 구강건조증 실험동물에서 타액 분비가 증가하였고, AQP5 의 발현 또한 증가하는 결과를 보고하였다. 또한 4-DAMP 로 유도 하여 구강건조증을 유발한 실험에서 생지황 추출 물을 경구 투여 시 타액 분비량과 $\mathrm{AQP5}$ 의 발현이 증가 한 것을 확인하는 연구결과도 보고되었다(Jung, 2010). 이 상의 연구결과를 바탕으로 AQP5의 발현이 타액 분비와 밀접한 연관성을 가진다는 것을 알 수 있었으며, cinnam- aldehyde 등과 같은 천연 물질이 $\mathrm{AQP5}$ 신호 체계를 활용 하여 구강건조증의 예방 및 치료를 위한 후보 물질로 제 시될 수 있을 것이라 사료된다.

\section{ACKNOWLEDGMENTS}

This work was supported by the National Research Foundation of Korea (NRF) grant funded by the Korea government (MSIT) (NRF-2017R1C1B5076722).

\section{CONFLICT OF INTEREST}

The authors have no conflict of interest with the publication of this article.

\section{REFERENCES}

Aframian DJ, Helcer M, Livni D, Robinson SD, Markitziu A, Nadler C. Pilocarpine treatment in a mixed cohort of xerostomic patients. Oral Dis. 2007. 13: 88-92.

Agre P, King LS, Yasui M, Guggino WB, Otterse OP, Fujiyoshi Y, Engel A, Nielsen S. Aquaporin water channels-from atomic structure to clinical medicine. J Physiol. 2002. 542: 3-16.

Braga MA, Tarzia O, Bergamaschi CC, Santos FA, Andrade ED, Groppo FC. Comparison of the effects of pilocarpine and cevimeline on salivary flow. Int J Dent Hyg. 2009. 7: 126-130.

Caulfueld MP, Birdsall NJ. International union of pharmacology. XVII. Classification of muscarinic acetylcholine receptors Pharmacol Rev. 1998. 50: 279-290.

Choi JS, Lim JY. Diagnosis and treatment of xerostomia. Korean J Otorhinolaryngol-Head Neck Surg. 2016. 59: 424-429.

Hopcraft MS, Tan C. Xerostomia: an update for clinicians. Aust Dent J. 2010. 55: 238-244.

Hossein N, Zahra Z, Abolfazl M, Mahdi S, Ali K. Effect of cinnamon zeylanicum essence and distillate on the clotting time. J Med Plants Res. 2013. 7: 1339-1343.

Ishikawa Y, Ishida H. Aquaporin water channel in salivary glands. Jpn J Pharmacol. 2000. 83: 95-101.

Jung MH. Effect of rehmanniae radix on salivary secretion enhancement in the rat thirst model. Graduate school of Kyunghee University. 2010.

Kim KY. Altered expression of sodium transporters and water channels following sympathetic and parasympathetic denervation in rat submandibular gland. Chonnam National University. 2004. 
Li X, Azlina A, Karabasil MR, Purwanti N, Hasegawa T, Yao C, Akamatsu T, Hosoi K. Degradation of submandibular gland AQP5 by parasympathetic denervation of chorda tympani and its recovery by cevimeline, an M3 muscarinic receptor agonist. Am J Physiol Gastrointest Liver Physiol. 2008. 295: 112-123.

Ma T, Song Y, Gillespie A, Carlson EJ, Epstein CJ, Verkman AS. Defective secretion of saliva in transgenic mice lacking aquaporin-5 water channels. J Biol Chem. 1999. 274: 20071 -20074 .

Matsuzaki T, Suzuki T, Koyama H, Tanaka S, Takata K. Aquaporin5 (AQP5), a water channel protein, in the rat salivary and lacrimal glands: immunolocalization and effect of secretory stimulation. Cell Tissue Res. 1999. 295: 513-521.

Melvin JE, Moran A, Turner RJ. The role of $\mathrm{HCO} 3$-and $\mathrm{Na}+/ \mathrm{H}+$ exchange in the response of rat parotid acinar cells to muscarinic stimulation. J Biol Chem. 1988. 264: 19564-19569.

Murdiastuti K, Purwanti N, Karabasil MR, Li X, Yao C, Akamatsu T, Kanamori N, Hosoi K. A naturally occurring point mutation in the rat aquaporin 5 gene, influencing its protein production by and secretion of water from salivary glands. Am J Physiol. 2006. 291: G1081-1088.

Neda G, Behrous HS, Alireza R, Shilan S. Effect of stress, anxiety and depression on unstimulated salivary flow rate and xerostomia. J Dent Res Dent Clin Dent Prospects. 2017. 11: 247 -252 .

Quartuccio L, Baldini C, Priori R, Bartoloni E, Carubbi F, Alunno A, Gandolfo S, Colafrancesco S, Giacomelli R, Gerli R, Valesini G, Bombardieri S, Salvatore De Vita the GRISS Group. Cryoglobulinemia in sjögren syndrome: A disease subset that links higher systemic disease activity, autoimmunity, and local B cell proliferation in mucosa-associated lymphoid tissue. The Journal of Rheumatology. 2017. 44: 1179-1183.

Satoh K, Narita T, Matsuki-Fukushima M, Okabayashi K, Ito T, Hidenobu Senpuku H, Sugiya H. E2fl-deficient NOD/SCID mice have dry mouth due to a change of acinar/duct structure and the down-regulation of AQP5 in the salivary gland. Pflugers Arch. 2013. 465: 271-281.

Screebny LM, Valdini A. Xerostomia: A neglected symptom. Arch Intern Med. 1987. 47: 1333-1337.

Smith JK, Siddiqui AA, Modica LA, Dykes R, Simmons C, Schmidt J, Krishnaswamy A, Berk SL. Interferon-alpha upregulates gene expression of aquaporin-5 in human parotid glands. J Interferon Cytokine Res. 1999. 19: 929-935.

Toshiyuki M, Takeshi S, Haruko K, Shigeyasu T, Takata K. Aquaporin-5 (AQP5), a water channel protein, in the rat salivary and lacrimal glands: immunolocalization and effect of secretory stimulation. Cell and Tissue Research. 1999. 295: 513-521.

Yuichiro Y, Yasuda M, Hashida K, Kadokura Y, Yamamoto T, Suzaki H. Mechanism of salivary secretion enhancement by byakkokaninjinto. Biological and Pharmaceutical Bulletin. 2008. 31: 431-435.

https://doi.org/10.15616/BSL.2020.26.2.93

Cite this article as: Choi $\mathrm{JH}$, Lee $\mathrm{JH}$, Kim $\mathrm{YH}$, Hyun KY, Park CM, Lee MK. Effects of Cinnamaldehyde on Salivary Gland Tissue in Xerostomia Model. Biomedical Science Letters. 2020. 26: 93-100. 